\title{
Uznání genocidy Arménů jako téma politického diskursu Arménie, Turecka a vybraných zemí EU ${ }^{1}$
}

\author{
Emil Souleimanov, Maya Ehrmann, Vincenc Kopeček²
}

\begin{abstract}
Recognition of the Armenian Genocide as an Issue in Political Discourse in Armenia, Turkey and selected EU Countries

The issue whether to legally recognize the tragic events of 1915 in Eastern Anatolia as a genocide remains a key political issue which drives an edge between Armenia and the Republic of Turkey. Through their European diaspora communities, the issue has also entered the domain of the European Union (EU), becoming even more controversial as Turkey is in the process of hotly contested EU accession talks. The present article uses the instruments of discourse analysis to focus on the current perceptions of the Armenian genocide in the various countries involved, specifically within the EU, Armenia and Turkey, in order to explore the political rationale bebind the commitment of various states to recognize or deny the aforementioned historical events as an act of genocide. After providing a brief historical overview of the 1915 events, we analyse internal EU perceptions of the "reality" of the Armenian genocide recognition, primarily in relation to Turkey's accession efforts. We then focus on the domestic discourses in Armenia and Turkey, with the goal of shedding light on the rationale behind both Yerevan's encouragement of genocide recognition and Ankara's unwillingness to recognize the genocide, as well as on the political implications of recognition and denial.
\end{abstract}

Keywords: Genocide Recognition, Armenia, Turkey, Caucasus, European Union.

\section{1. Úvod}

Je jen málo historických událostí, které i po téměř sto letech působí tolik rozepř́i jako tzv. arménská genocida. ${ }^{3}$ Zdaleka se přitom nejedná jen o to, že se jednotliví historikové neshodnou na interpretaci tohoto tragického období jak arménských, tak tureckých dějin. Pojem arménská genocida totiž opustil sféru historiografického výzkumu a zapustil kořeny i ve sféře politiky, a to jak vnitřní politiky v Arménii, Turecku i řadě dalších zemí, tak politiky mezinárodní. Jako taková pak arménská genocida přestala být výhradním tématem pro historiky, ale stala se také tématem výzkumu pro politickou vědu.

Právě z pozice politické vědy přistupuje $\mathrm{k}$ arménské genocidě i naše studie. I když se nemůžeme některým historickým aspektům arménské genocidy vyhnout, náš cíl leží jinde než ve

\footnotetext{
1 Emil Souleimanov uskutečnil výzkum na této práci v rámci Programu rozvoje vědních oblastí na Univerzitě Karlově (PRVOUK), P17Vědy o společnosti, politice a médiuch ve výzvách doby, řešeném na Fakultě sociálních věd Univerzity Karlovy v Praze. Vincenc Kopeček uskutečnil výzkum na této práci v rámci projektu Separatistické konflik:ty kavkazské oblasti v geopolitických souvislostech (interní grantová soutěž specifického vysokoškolského výzkumu, Př́rodovědecká fakulta Ostravské univerzity, č. projektu SGS11/PřF/2010/6102).

2 Doc. PhDr. Emil Souleimanov, Ph.D., katedra ruských a východoevropských studií, Fakulta sociálních věd, Universita Karlova v Praze, U kříže 8, 15800 Praha 5. RNDr. Vincenc Kopeček, Ph.D., katedra sociální geografie a regionálního rozvoje, Př́rodovědecká fakulta, Ostravská univerzita, Chittussiho 10,710 00 Ostrava - Slezská Ostrava. Maya Ehrmann je absolventkou oborů státní správa, diplomacie a strategie na Interdisciplinary Center ve městě Herzliya, Izrael

3 Autoři v článku užívají pro události z let 1915-1916 termíny arménské genocida či genocida Arménů. Tento termín je níže v textu podroben detailnější diskusi, na tomto místě je však třeba zdůraznit, že předložený text se nesnaží rozhodnout, zda uvedené události byly či nebyly genocidou, ale věnuje se percepci zmiňovaných událostí a konstrukci diskurzu arménské genocidy.
} 
zkoumání a interpretaci historické události, resp. událostí. Tématem naší studie jsou sociálně konstruované významy pojmu arménská genocida jako takového. Konkrétně se zaměřujeme na politický diskurz arménské genocidy ve vybraných členských státech EU, v Arménii a v Turecku, přičemž se věnujeme jak vnitřním či vnějším faktorům, které percepci této historické události a následně formulaci politického diskurzu ovlivňují, tak mezinárodně-politickým či geopolitickým důsledkům vyplývajícím ze střetu rozdílných politických diskurzů.

Zatímco studií věnujících se arménské genocidě z historiografického či historickopolitického hlediska je dostatek, přičemž řada z nich sklouzává, či dokonce prvoplánově obhajuje arménský či turecký pohled na věc, ${ }^{4}$ problematika samotné konstrukce diskurzů arménské genocidy v jednotlivých národních komunitách a dopad těchto diskurzů na mezinárodní politiku je v politickovědní literatuře stále relativně poddimenzována. Studie, které se těmto tématům zejména v posledních letech věnují, se jimi totiž zabývají převážně odděleně, ač se v zásadě jedná o spojené nádoby. Věnují se tak arménskému nebo tureckému diskurzu (např̀. Bilali 2013; Dixon 2010; Maksudyan 2009; Cooper, Akçam 2005;), zahraničně-politickým vlivům na tvorbu těchto diskurzů (např. Açar, Rüma 2007), či dopadům jednoho nebo druhého diskurzu na mezinárodněpolitické dění, zejména pak co se týče vstupu Turecka do EU (např. Altinbaş 2011; Bürgin 2010; Hülsse 2006). Texty zabývající se bilaterálními turecko-arménskými vztahy také ponechávají národní diskurzy arménské genocidy poněkud stranou a plně je nezakomponovávají do analýzy (např. Valigholizadeh, Zaki, Barani 2013), a pokud ano, snaží se o „balancovaný“ pohled na problém, a ne o analýzu diskurzů samotných (např. Zekian 2010).

Struktura textu je následující. Nejprve se věnujeme výběru studovaných př́padů a metodologii, poté se zaměřujeme na samotný termín genocida a jeho užívání ve spojení s adjektivem „arménská“, což je nutné jak z hlediska konceptuálního, tak vzhledem k politické citlivosti studovaného fenoménu, a konečně také přistupujeme ke třem případovým studiím Arménii, Turecku a vybraným zemím EU.

\section{Výběr př́padů a metodologie}

Problematika arménské genocidy se pochopitelně nejvíce dotýká dvou národních společenství, tureckého a arménského, jejichž příslušníci byli před téměř sto lety hlavními aktéry událostí, které jsou jako arménská genocida nazývány. Příslušníci těchto národních společenství se sice koncentrují do dvou států, jež jimi bývají chápány jako státy národní, totiž Turecké a Arménské republiky, zároveň však také existují početné turecké a zejména arménské diaspory, které téma arménské genocidy přenášejí i do vnitřní politiky jiných zemí, např. Francie, USA, či Německa. Klasickým př́padem je zde zejména Francie, která roku 2001 formálně uznala, že diskutované události byly genocidou. 23. ledna 2012 navíc francouzští zákonodárci prrijali zákon kriminalizující popírání arménské genocidy a trestající tento čin až jedním rokem vězení a pokutou 45 tisíc eur. Zákon byl sice koncem února téhož roku vrácen Ústavní radou, ale i tak vrhnul Francii a Turecko do nového kola diplomatických přestřelek. Turecko dokonce hrozilo

\footnotetext{
${ }^{4}$ Detailně se arménskou genocidou zabývá celá řada textů, z nichž vybíráme některé z těch novějších. Z arménského pohledu se událostem věnují např. Kérvorkian (2011), Hovannisian (2007) či Dadrian (2004), z tureckého např̀. Gunter (2011), některé práce jsou výsledky širších autorských kolektivů a poskytují prostor více interpretacím, např. Suny, Göçek a Naimark (2011), alternativní turecký pohled představuje např. Akçam (2006). Dnes již historickými dokumenty, popisujícími masakry arménského obyvatelstva, jsou Bryce a Toynbee (1916), Morgenthau (1918) či Lepsius (1919).
} 
zavedením permanentních sankcí a přerušením diplomatických a strategických vazeb (Chrisafis a Hopkins 2011).

Určitému zhoršení vztahů s Tureckem pak čelí prakticky všechny země, jejichž parlamenty či jiné politické orgány oficiálně uznaly ${ }^{5}$ arménskou genocidu. ${ }^{6}$ To se týká i vztahů mezi Tureckem a EU, jejíž členské státy tvoři významnou část zemí, které arménskou genocidu uznaly, přičemž stejně se již roku 1987 zachoval i Evropský parlament. Otázka vstupu Turecka do EU proto bývá často spojována s tureckým uznáním arménské genocidy (např. Oğuzlu 2012: 234; Vidlickova 2012: 2; Bürgin 2010; Hakki 2006: 464-465). Proto byly právě členské země Evropské unie vedle Arménie a Turecka vybrány jako třetí prípadová studie, na níž budeme diskurz arménské genocidy sledovat.

Z metodologického hlediska je text založen na foucaultovské (mj. Foucault 1994: 7-40) diskurzivní analýze. Diskurz tak nechápeme jako určitou společenskou činnost, např́klad promluvu, jak by tomu bylo mezi jinými u Fairclougha, ale jako významovou strukturu, jako systém pravidel, prostor, v němž se vytvářejí aktuální výpovědi (Beneš 2008: 106). Diskurz je v tomto chápání politický fenomén, který jak formuje jednotlivé výpovědi, tak je výpověd’mi formován (srov. Edwards a Potter 2001: 14-15). Politický boj tak probíhá v rámci diskurzu, ale předmětem zápasu je i samotný diskurz (Nekvapil 2006: 265). Studovat takto chápaný diskurz lze ovšem pouze přes dílčí výpovědi, avšak v tomto případě, na rozdíl od jiných typů diskurzivní analýzy, není předmětem studia lingvistická stránka textu, ale pouze jeho obsah (Nekvapil 2006: 264); jedná se spíše o dlouhodobé sledování mnoha informačních kanálů, kladení jednotlivých vyjádření vedle sebe a jejich porovnávání (Beneš 2008: 106).

Foucaultovská diskurzivní analýza byla zvolena právě z výše uvedeného důvodu. Ač se jedná o nepřiliš rigorózní vědeckou metodou (srov. Beneš 2008: 107), má pro námi sledované cíle nespornou přednost. Nesledujeme totiž lingvistické vlastnosti textu, zajímá nás významová struktura, v níž se debata o arménské genocidě odehrává, struktura, která tuto debatu formuje a je jí sama formována.

Samotná analýza by nebyla možná bez předchozího dlouhodobého sledování dané problematiky, během něhož byli autoři schopni v hrubých rysech vystihnout jednotlivé studované diskurzy arménské genocidy. Využívány zde byly převážně sekundární zdroje, které jsou průběžně citovány $\mathrm{v}$ textu. Tyto diskurzy „v hrubých rysech“ byly konfrontovány s konkrétními promluvami politických aktérů, za něž jsou v této studii považována vyjádření oficiálních státních institucí, politiků jako individualit a také dalších veřejně činných osob (kulturní a vědecká elita), vstupujících svými výroky do veřejné sféry a podílejících se tak na (re)produkci diskurzu.

Skrze konfrontaci s konkrétními výroky byl diskurz „v hrubých rysech“ v podstatě hermeneuticky reinterpretován, přičemž část $\mathrm{z}$ těchto vyjádření je $\mathrm{v}$ textu průběžně citována. Kritérium výběru těchto vyjádření spočívá $\mathrm{v}$ tom, nakolik dokáží daný diskurz věrně ilustrovat. Zejména $\mathrm{v}$ případě Turecka se ovšem objevila vyjádření, která dominantnímu diskurzu značně odporovala, a $\mathrm{v}$ našem textu tak $\mathrm{v}$ tomto př́padě vystupují $\mathrm{v}$ zásadě dva odlišné diskurzy arménské genocidy, ilustrované zcela rozdílnými vyjádřeními. Veškerá tato vyjádření byla

\footnotetext{
${ }^{5}$ V současnosti se jedná o následující státy: Austrálie, Argentina, Belgie, Kanada, Chile, Kypr, Francie, Německo, Řecko, Itálie, Litva, Libanon, Nizozemsko, Polsko, Rusko, Slovensko, Švédsko, Švýcarsko, Uruguay, Vatikán, Venezuela, USA a Evropská unie (Vidlickova 2012: 9; ANCA 2013).

$6 \mathrm{~V}$ př́padě rezoluce zahraničního výboru amerického Kongresu z roku 2010 Turecko vyhrožovalo přerušením vojensko-strategické spolupráce s USA, v př́padě rezoluce švédského parlamentu téhož roku pak Turecko zrušilo plánovaný švédsko-turecký summit a podobně jako v americkém prrípadě stáhlo ze země svého velvyslance (Tait, MacAskill 2010; Peterson 2010).
} 
dohledána z veřejně př́stupných zdrojů, zejména oficiálních prohlášení, akademických textů či novinových článkủ. Oficiální vyjádř̌ení byla nalezena $\mathrm{v}$ závislosti na studovaném tématu (např̀ Early Day Motion v britském Parlamentu), podobně tomu bylo i u akademických textů; systematicky byly sledovány významné anglojazyčné deníky Guardian a Telegraph, světové zpravodajské servery $\mathrm{BBC}$ a $\mathrm{CNN}$, dvě periodika pokrývající anglojazyčný arménský prostor (Asbarez a Armenian Weekly), jedno periodikum armenojazyčné, ovšem disponující anglickou jazykovou mutací (Hetq) a dvě periodika turecká (Hürriyet a Today's Zaman). ${ }^{7}$ Sledovány byly vždy online verze daných periodik a využíváno bylo vyhledávače integrovaného do př́slušného serveru (hledaná fráze ,armenian genocide“). Časové hledisko prritom při výběru výpovědí nehrálo primární roli; pokud to vyhledávač dovolil, byly články řazeny podle relevantnosti vůči hledané frázi a nikoliv podle data publikování. Pokud touto možností vyhledávač nedisponoval a nalezených článků bylo více než 100, bylo vyhledávání zpřesněno pomocí dodatečných kritérií (např. „Turkey“, „Armenia“, „,recognition“).

\section{Genocida: právo, věda a politika}

Termín genocida byl poprvé použit polsko-židovským právníkem Raphaelem Lemkinem v roce 1944, a to v souvislosti s masovou likvidací určitých skupin obyvatelstva, zejména Židů, nacistickou Třetí řiší během druhé světové války (srov. Jones 2006: 8-12; Martin 1981: 124). Podle Úmluvy o zabránění a trestání zločinu genocidy, júž jsou vázány všechny státy světa, je genocida, „at' spáchan[á] v míru nebo za války, [...] zločinem podle mezinárodního práva“ a je definována jako činy spáchané „, $\mathrm{v}$ úmyslu zničit úplně nebo částečně některou národní, etnickou, rasovou nebo náboženskou skupinu jako takovou“. Oněmi činy se pak rozumí usmrcení př́slušníků takové skupiny, způsobení těžkých tělesných ublížení nebo duševních poruch členům takové skupiny, úmyslné uvedení kterékoli skupiny do takových životních podmínek, které mají přivodit její úplné nebo částečné fyzické zničení, zavádění opatření směřující $\mathrm{k}$ tomu, aby se $\mathrm{v}$ takové skupině bránilo rození dětí, a konečně také násilné převádění dětí z jedné skupiny do jiné (UN 1948).

Z právního hlediska je tedy přinejmenším složité posuzovat události, které naplňují výše uvedené znaky, ale byly spáchány před druhou světovou válkou, jako genocidy. Pokud by jejich pachatelé byli stále na živu, je jen velmi obtížně představitelné, aby byli národními soudy či Mezinárodním trestním soudem souzeni za genocidu. Jejich činy by sice pravděpodobně naplňovaly skutkové podstaty jiných závažných trestných činů, nicméně souzení za genocidu by porušovalo jednu z hlavních právních zásad, a to zákaz retroaktivity.

Vedle genocidy coby termínu právního však existuje i genocida coby termín vědecký. To, že termín je recentní, neznamená, že události obdobného charakteru se neděly dříve; slovy Leo Kupera (1981: 9) - „slovo je nové, ale koncept prastarý“. Genocida tak vstoupila i do společenskovědní teorie, nepanuje však shoda na tom, o jak široký koncept se jedná, a tedy ani na tom, které události lze za genocidu označovat. Převážná část autorů se alespoň shodne na tom, že genocidu od jiných masových násilných činů odlišuje zejména záměr pachatelů částečně či zcela určitou skupinu obyvatelstva zlikvidovat (Jones 2006: 21). Někteří autoři dokonce sestavili obsáhlé seznamy masakrů, které považují za genocidu, sahající od starověku až po současnost (např. Kiernan 2007).

\footnotetext{
${ }^{7}$ To, že bylo dané periodikum sledováno, nutně neznamená, že je z něj níže v textu citováno. Články ze sledovaných periodik však byly využity při hermeneutické reinterpretaci diskurzu.
} 
Zároveň se vstupem termínu genocida do světa vědy vstoupil tento termín i do veřejného či populárního diskurzu, a to v podstatě jako označení pro nejhorší možný zločin (Wald 2007: 624; Moshman 2001: 440), přičemž často nabírá podobu jakési „nálepky“ (Kelly 2008). Svůj podíl na tomto stavu nesou i nedávné, značně medializované události, které znaky genocidy naplňovaly (např. během války v bývalé Jugoslávii, etnického konfliktu ve Rwandě, bojů v Dárfúru apod.) a jejichž pachatelé jsou stíháni mezinárodním společenstvím, at' již prostřednictvím Mezinárodního trestního tribunálu pro bývalou Jugoslávii, Mezinárodního tribunálu pro Rwandu či Mezinárodního trestního soudu zř́zeného již podle Rímského statutu a s globální působností.

Označování určité události za genocidu se konečně stalo i nástrojem politického boje, a to hned v několika rovinách. Někdy se jedná o zpytování vlastní historie a snahu o obrození kultury marginalizovaných domorodců, např. původních obyvatel Severní Ameriky (např. Kurtiş, Adams, Yellow Bird 2009; Brave Heart, DeBruyn 1998; Jaimes 1992) nebo australských Aboriginců (např. Moses 2004; Bartrop 2001; Tatz 2001), v obou prrípadech obětí evropských osadníků. Jindy se jedná o politický nástroj v mezinárodní politice, z poslední doby lze zmínit např. tzv. genocidu Čerkesů (např. Richmond 2013; Bullough 2010: 15-144), o jejíž uznání Ruskem usilují představitelé čerkeského exilu v Turecku a jimž se dostává silné podpory z Gruzie (Siroky, Dzutsev 2012; Lomsadze 2011), prrípadně masakr etnicky ázerbájdžánského obyvatelstva v městečku Chodžaly během války o Náhorní Karabach, který byl veden arménskými jednotkami (de Waal 2012: 182-184) a jejž ázerbájdžánská strana systematicky označuje za genocidu (např. Mustafayeva, Garayev 2013; Suleymanov 2006).

\section{Historické okolnosti arménské genocidy}

K tragédii, která je někdy označovaná za první genocidu 20. století, došlo na území Osmanské ř́še v letech 1915-1916. Počátky konfliktu můžeme hledat hluboko v 19. století v hospodářských sporech mezi usedlými Armény a nomádskými Kurdy, jejichž notáblové byli faktickými vládci regionu, který osmanská vláda neměla vždy plně pod kontrolou (Košt’álová 2011: 14). Východoanatolští arménští rolníci byli často napadáni kurdskými kmeny a předáci těchto kmenů po nich vyžadovali platbu „daně za ochranu“ ${ }^{8}$ V reakci na to Arméni koncem 19. století vyvolali několik de facto protikurdských nepokojů a dovolávali se osmanského sultána, aby je zbavil kurdské „ochrany“ a zavedl v regionu prrímou správu. Nicméně jejich stížnosti nebyly vyslyšeny. Osmanská vláda se obávala opakování vývoje na Balkáně, kde ostatní evropské mocnosti intervenovaly do vnitroosmanských záležitostí kvůli ochraně tamních křest’anů, což se často dělo na úkor muslimského obyvatelstva. ${ }^{9}$ Vysoká porta místo toho potrestala Armény tím, že iniciovala vypuknutí masakrů. Jejich pachateli přitom údajně nebyly pouze polovojenské kurdské jednotky s minimálním výcvikem, které prakticky nepodléhaly kontrole centrálních orgánů, ale také pravidelná osmanská armáda. Během násilností z let 1894-1896 přřšlo podle různých odhadů o život až čtvrt milionu Arménů (Suny 1993: 100-106).

Důsledkem těchto událostí byla rostoucí politizace arménských požadavků, kdy konflikt stále zřetelněji nabíral etnické a zčásti i náboženské dimenze. $\mathrm{V}$ některých kruzích, př́edevším $\mathrm{v}$

\footnotetext{
8 Arméni coby křest’ané dlouho nesměli v Osmanské ř́řsi nosit zbraně, jezdit na koni apod., což neplatilo pro muslimské Kurdy. To se změnilo po roce 1856, kdy byl vydán Islâhat Hatt-ı Hümâyûnu, dekret zrovnoprávňující nemuslimy (Ágoston, Masters 2009: 185-186).

${ }^{9}$ K vývoji na Balkáně viz Poulton (2000: 51-53).
} 
arménské diaspoře, se dokonce začaly objevovat požadavky na anexi „Západní Arménie“10 carským Ruskem. Mezi radikální arménskou inteligencí vzrůstaly separatistické, či spíše iredentistické, tendence. Stereotypní obraz „kurdského bandity“, který byl rozšířen mezi arménskými rolníky východní Anatolie, brzy nahradil silně zpolitizovaný obraz „tureckého vraha“. Tak se zrodila „arménská otázka“ coby výrazný jev evropské politické scény na přelomu 19. a 20. století. Antagonismus mezi muslimy a Armény kulminoval během první světové války, kdy vládnoucí osmanská strana Výbor jednoty a pokroku (Ittibat ve Terakki Cemiyeti) nařídila zákonem o přesídlení (Tehcir Kanunu) organizovaný odsun - a podle některých zdrojů i masakry „rebelujícího“ arménského obyvatelstva. Násilné deportace byly zdůvodňovány ochranou východních hranic říše a podle různých odhadů jim padlo za obět’ 300 tisíc (údaje tureckých zdrojů) až 1,5 milionu (údaje arménských zdrojů) Arménů (Walker 1997: 271-272). Jedním z důvodů této diskrepance je mimo jiné i neshoda na časovém ohraničení arménské genocidy/deportací, kdy turečtí historici a západní osmanologové uvádí počty obětí vlastních deportací, zatímco $\mathrm{v}$ arménské historiografii a západní armenistice se stále výrazněji prosazuje názor, že za genocidu Arménů by se mělo pokládat celé období válek v letech 1915-1923.

Arménská genocida znamenala konec tisíce let trvající př́tomnosti Arménů ve východní Anatolii a vlivných arménských komunit v mnoha osmanských městech. Vyvolala masovou emigraci těch, kdo př̌žili deportace především do Západní Evropy, Ruska a do Jižní i Severní Ameriky. Uprchlíci z Osmanské říše vytvořili novou diasporu (oproti starodávným arménským obcím, které byly v Evropě již od středověku) a jejich lobby stále představuje výraznou politickou sílu zejména v Rusku, Francii a v USA (srov. např. Baser, Swain 2009; Tölölyan 2000; Paul 2000; Shain 1994: 821; Suny 1993: 213-230).

Bezprostředně po konci první světové války proběhly v Osmanské ř̌šsi pod nátlakem vítězných evropských mocností soudy s osobami, které byly činěny zodpovědnými za masakry Arménů. Enver Paşa, Cemal Paşa a Talât Paşa, tři hlavní členové Výboru pro jednotu a pokrok a ministři mladoturecké vlády, kteři byli považováni za hlavní strůjce genocidy, však uprchli do zahraničí, a byli tak k trestu smrti odsouzeni v nepř́tomnosti. Po nástupu Mustafy Kemala k moci ale evropské státy $\mathrm{v}$ čele s Británií podlehly nátlaku nového tureckého vůdce, tribunály byly zastaveny a z vězení na Maltě byli propuštěni turečtí vězni (Akçam, Dadrian 2011; Dadrian 1991; 1997). Předpokládaní strůjci arménské genocidy se tak stali cílem tzv. operace Nemesis, která byla započata na devátém kongresu Arménské revoluční federace (Haj Heghapochakan Dašnakcutjun) v Jerevanu roku 1919. Na černou listinu se dostalo 200 osob zodpovědných podle dašnaků za genocidu. Operace trvala po celá dvacátá léta a dašnakům se podařilo hlavní strůjce genocidy zabít. Talât byl zabit v roce 1921 v Berlíně, Cemal roku 1922 v Tbilisi, Enver téhož roku v Buchaře v Tádžikistánu (Hyland 1991: 21-22). Další vlna útoků na turecké cíle přišla v 70. a 80. letech 20. století, přičemž nejvyšší počet těchto útoků má na svém kontě teroristická organizace známá jako Arménská tajná armáda pro osvobození Arménie (Armenian Secret Army for the Liberation of Armenia, ASALA). ${ }^{11}$

\footnotetext{
10 Po téměř jednom století bojů mezi Perskou a Osmanskou říší bylo zuhabskou dohodou z roku 1639 území obývané Armény rozděleno mezi tato dvě impéria. Většinu východní části, která připadla Persii, získalo v letech 1804-1828 carské Rusko, přičemž v roce 1878 získalo i část Osmany ovládané západní části (Kars, Ardahan a Artvin). „Východní Arméniî “ je tak nazývána oblast kontrolovaná Ruskem, „Západní Arménií “ pak oblast kontrolovaná Osmanskou rríší.

${ }^{11}$ Bliže k arménskému terorismu viz např. Dugan et. al. (2009), Tölöyan (1992) nebo Hyland (1991).
} 
Arménská diaspora i vláda $\mathrm{v}$ Jerevanu opakovaně požadují, aby turecká vláda uznala arménskou genocidu. Dávné masakry, stejně jako násilný konflikt v Náhorním Karabachu, ${ }^{12}$ prohloubily nedůvěru Arménů vůči Turkům (a také vůči Ázerbájdžáncům, kteří jsou v arménském kolektivním povědomí kvůli etnické a jazykové spř́zněnosti s Turky často srovnáváni). Turecko naopak odmítá nazývat události z roku 1915 genocidou a často poukazuje i na násilnosti páchané Armény na Turcích, a to nejen během první světové války, ale i těch, které mají na svědomí arménští teroristé. Diplomatické vztahy obou zemí byly až do nedávna více než chladné a pokusy o nezaujatou akademickou analýzu genocidy také selhávají. ${ }^{13}$

\section{Vybrané členské země EU a diskurz arménské genocidy}

Ve většině západoevropských zemí je uznání arménské genocidy ze strany Turecka z různých důvodů pokládáno za jednu ze základních podmínek pro vstup země do EU, přičemž mezi státy, které oficiálně uznaly arménskou genocidu, se řadí i významné členské státy EU jako Francie, Německo, Itálie či Polsko. Už z tohoto faktu je zřejmé, že otázka uznání genocidy není bezvýznamná. Z vyjádření některých zemí a především pak Evropského parlamentu vyplývá, že i když uznání arménské genocidy není zákonnou podmínkou pro vstup do EU, je pokládáno za zcela nezbytné. Např. v roce 2000 vydal zahraniční výbor švédského parlamentu prohlášení v tomto znění: „Oficiální uznání genocidy Arménů je důležité a nezbytné. [...] Stálý výbor [pro zahraniční věci] je toho názoru, že čím větší otevřenost Turecko projeví, tím silnější bude jeho demokratická identita. [...] Je velmi důležité, aby se dospělo k větší otevřenosti a historickému pochopení událostí z roku 1915 a z let následujících“ (ANI 2000). Ačkoliv se v tomto prohlášení neuvádí, že uznání arménské genocidy ze strany turecké vlády by bylo prrímo podmínkou pro vstup do EU, text naznačuje, že takové uznání je nezbytné pro etablování turecké demokracie, což lze chápat jako odkaz na jednu z př́stupových podmínek tzv. kodaňských kritérií (EC 1993).

Dalším ilustrativním př́padem je prohlášení, které v roce 2006 podepsalo 60 členů britské dolní sněmovny, v němž označuje vládu „turecké Osmanské říše“ a Výbor jednoty a pokroku za pachatele genocidy Arménů a Asyřanů a „,[...] naléhá na vládu Spojeného království, aby vyzvala Evropskou unii k zařazení oficiálního tureckého uznání genocidy Arménů a Asyřanů z roku 1915 mezi podmínky členství Turecka v EU“ (Parliament 2006). V tomto př́padě tedy britští poslanci jednoznačně deklarují uznání arménské genocidy Tureckem jako nezbytné pro vstup země do EU a nabádají Unii, aby takové uznání oficiálně požadovala coby předpoklad členství.

Výzvy vůči Turecku, aby uznalo genocidu Arménů, přitom nevznáší pouze množství evropských států, z nichž některé by takové uznání rády prosadily jako podmínku pro vstup do EU. Důležitost uznání genocidy zdůraznily i některé orgány Evropské unie. Např́klad Evropský parlament v roce 2006 ve zprávě hodnotící pokrok Turecka při prrípravách na vstup do EU zdůraznil, že: „[...] ačkoliv uznání genocidy na Arménech není formálně jedním z kodaňských kritérií, je pro Turecko na cestě k př́stoupení nezbytné uznat vlastní minulost a vyrovnat se s nî“ (EP 2006). Evropský parlament, stejně jako mnoho evropských států, tvrdí, že uznání arménské genocidy je velice žádoucím krokem, byt' není oficiálně uvedeno jako podmínka pro vstup do EU. Pokud však mnohé členské státy EU oficiálně uznaly arménskou genocidu a současně

\footnotetext{
${ }^{12}$ Náhorní Karabach je separatistická politická entita na Jižním Kavkaze, která se s vojenskou podporou Arménské republiky politicky oddělila od Ázerbájdžánu, což však mezinárodní společenství neuznalo a nadále považuje Náhorní Karabach za de iure součást Ázerbájdžánu.

${ }_{13}$ Pro přehled o arménsko-tureckých vztazích, včetně neúspěšného pokusu o otevření hranic např. Valigholizadeh et. al. (2013), Phillips (2012) nebo Gunter a Rochtus (2010).
} 
Turecko potřebuje souhlas členských států pro svi̊j vstup do Unie, potom je jeho odmítnutí uznat, že události z roku 1915 byly genocidou, zásadní překážkou v jeho prŕstupovém procesu, nebot’ lze předpokládat, že tyto členské státy jeho vstup nepodpoř́.

\section{Uznání genocidy: arménská perspektiva}

Vedle morálních a etických argumentů existují také specifické vnitřní i vnější politické faktory, kterými lze vysvětlit jednání současné arménské vlády. Oživení zájmu o arménskou genocidu může posílit národní jednotu, která byla poněkud narušena po vítězství v Náhorním Karabachu v důsledku „hospodářských, demografických a politických krizi“", které Arménii postihly v době po konfliktu (Mammadov 2011).

Nepřetržité udržování protitureckých (ale i protiázerbájdžánských) nálad vede k vysoké míře sociální soudržnosti, jaká je zapotřebí v prrípadě, že by v budoucnu opět vypukl ozbrojený konflikt. V tomto smyslu udržení sociální koheze závisí na ustanovení a udržování společného nepř́tele. Tuto tezi podporuje také fakt, že po vítězství Arménie, kdy se hrozba představovaná turkickým nepř́telem stala méně bezprostřední, arménský smysl pro solidaritu poněkud upadl. Někteří arménští intelektuálové navíc tvrdí, že „kdyby tehdy [na počátku devadesátých let] Turecko uznalo svou odpovědnost za zničení anatolských Arménů, politický spor o Karabach mohl být $\mathrm{v}$ zásadě vyřešen nenásilně“ (Cheterian 2010). Tito intelektuálové se takto snaží naznačit spojitost mezi událostmi roku 1915 a konfliktem v Náhorním Karabachu, čímž staví Turecko do role věčného nepř́tele a posilují antiturecké resentimenty. Protiturecké a protiázerbájdžánské tóny lze nalézt i v oficiálních vyjádřeních arménských politiků. Např. arménské ministerstvo zahraničí prohlásilo: „Ázerbájdžán zkresluje povahu a důvody konfliktu a jeho důsledků [...] a dále využívá prŕijmy $\mathrm{z}$ těžby ropy ke zvyšování vojenského rozpočtu a $\mathrm{k}$ nákupu značného množství útočných zbraní, čímž výrazně porušuje mnohé dohody a závazky v oblasti bezpečnosti a obranné politiky. [...] Ázerbájdžánské snahy získat jednostranné ústupky pomocí hrozeb užití síly jsou nadále hlavní překážkou pro kompromisní urovnání konfliktu. [...] Ázerbájdžán odmítá navázat s Arménií diplomatické styky a udržovat politiku dobrého sousedstvi“" (MFA 2011a).

Toto prohlášení je zjevně kritické k Ázerbájdžánu a zdůrazňuje oficiální postoj, že existuje reálná hrozba nového ozbrojeného konfliktu. Takto vnímaná hrozba posiluje obraz Ázerbájdžánu jako společného nepřítele. Přetrvávající nepřátelství vưči Ázerbájdžánu dále posiluje antiturecké resentimenty, protože Turecko stálo během války o Náhorní Karabach na straně Ázerbájdžánu. Stejně tak udržování nepřátelství s Tureckem je posilováno snahou vytvořit spojitost mezi genocidou Arménů a karabašskou válkou.

Arménské ministerstvo zahraničí dále tvrdí, že „od roku 1991 byly učiněny pokusy o normalizaci bilaterálních vztahů, které skončily neúspěšně kvưli pozici Turecka“ (MFA 2011b). Obě vyjádření ukazují, že oficiální postoj Arménie vưči Turecku a Ázerbájdžánu je více než chladný, přičemž vinu za stagnaci vztahů s oběma zeměmi Arménie prričitá výhradně Turecku a Ázerbájdžánu. Udržování takových resentimentů je klíčové pro vytvoření sociální koheze. Protiturecké postoje související s arménskou genocidou jsou posilovány s využitím problematiky Náhorního Karabachu. Společenská soudržnost je přitom zásadní, nebot' bez schopnosti sjednotit se proti společnému nepř́teli by se výrazně snížila šance na vítězství a úspěch preventivních opatření $\mathrm{v}$ př́padě obnovení či znovuvypuknutí ozbrojeného konfliktu.

Sdílení obrazu společného nepř́tele navíc přispívá ke sjednocení Arménů žijících v samotné Arménii s početnou diasporou, přičemž Arménů žijících v zahraničí je zhruba dvakrát více než těch, kteří žijí přímo v Arménii (Cohen 2008: 52). Početné arménské komunity v zahraničí jsou 
důležitou součástí arménského národního společenství a někdy také mocným nástrojem, který Arménská republika využívá především ve svém boji za mezinárodní uznání arménské genocidy. Přitom právě Turecko a popírání arménské genocidy jsou témata, která diasporu s Arménií spojují. Zahraniční arménské obce hrají důležitou roli, nebot’ neustále tlačí na místní vlády, aby uznaly arménskou genocidu a vyvíjely tlak na Turecko, aby učinilo totéž.

Jistá část arménských politiků a intelektuálů $\mathrm{v}$ Arménii i v diaspoře je navíc př́esvědčena, že trauma z genocidy a snaha o napravení dějinné křivdy coby výrazné motivy arménského nacionalismu mohou pomoci zpomalit asimilaci nejmladších generací diasporních Arménů a posilují jejich pocit sounáležitosti s vlastí. Intelektuálové jako Bakalian tvrdí, že „arménská zkušenost být nenáviděn až k smrti se stala zásadním motivem, který dnes definuje a sjednocuje všechny Armény v diaspoře, a do určité míry i v Arménii“ (Papazian 1995: 55-56). Snaha prosazovat uznání genocidy a udržet vzpomínku na ni v kolektivním povědomí jsou elementy výrazně přispívající $\mathrm{k}$ sociální kohezi arménského národa. Tato soudržnost navíc umožňuje mladým členům diasporních komunit vytvářet pocit solidarity a př́slušnosti $\mathrm{k}$ Arménii. Během udílení výroční ceny „za významný příspěvek k uchování arménské identity“, pořádaného arménským ministerstvem pro diasporu, zaznělo, že: „[t]ím, že mladí pokračují v osvojování si znalostí o těchto strastech, [...] utvárejí si své vlastní pohledy na svět a hodnotové systémy. Každý mladý člověk nazírá svou vlast svým vlastním způsobem a tyto studie dávají mladým jedinečnou př́ležitost poznat vlast vlastním pohledem“ (Mutafyan 2011).

Toto vyjádření naznačuje, že obtíže, jimž museli Arméni čelit, včetně genocidy, jsou sjednocujícími faktory. Navíc užití pojmu „vlast“ místo „Arménie“ má vytvořit pouto mezi Arménií a diasporou. Bakalian (1993: 3) dodává, že „dokonce pravnuci původních imigrantů si zachovali silnou arménskou identitu a smysl pro národní soudržnost"“.

Výsledkem politiky posilování soudržnosti je rostoucí finanční podpora, kterou Arménii poskytují zahraniční arménské obce (viz např. Lowell, Gerova 2004: 12; Manaseryan 2004; Gregg 2002: 23-24). Vliv významných arménských lobbistických skupin, které se zaměrují především na prosazování oficiálního uznání genocidy ve svých zemích (Avakian 2010: 205-206; Gregg 2002: 19-20), vede k rostoucímu významu diaspory pro zahraniční politiku Arménie. Zámořské komunity, které podporují aktuální vládní postoj ohledně arménské genocidy a karabašského konfliktu, také do určité míry legitimizují v očích veřejnosti elity z kruhů kolem prezidenta Serže Sargsjana, z nichž mnozí jsou spojováni s nepotismem, korupcí a jinými kriminálními aktivitami, ale stále zastávají své pozice (srov. např. ICG 2012: 3-6). Tato legitimizace napomáhá potlačování opozice.

$\mathrm{V}$ neposlední řadě část arménských intelektuálů a politiků podporuje uznání genocidy, protože by to pomohlo získat od Turecka finanční reparace (Petrosjan 2011). Uznání genocidy bývá totiž chápáno jako základní předpoklad finančních kompenzací za arménské majetky zkonfiskované či ztracené během událostí z roku 1915 (Bedrosyan 2011). Dle arménských zdrojů je „formální uznání genocidy Arménů podmínkou sine qua non pro jakýkoliv pokus či proces vedoucí k obnově spravedlnosti“" (Asbarez 2012). Na druhou stranu někteři mohou namítat, že právě obavy z finančních či dokonce územních ztrát brání Turecku oficiálně uznat genocidu Arménů (Yacoubian 2010).

Vedle finanční stránky věci je totiž v posledních letech stále častěji diskutována otázka navrácení historického arménského území, tzv. „Západní Arménie“, která posledních devět dekád patř́ Turecku. Podobné spekulace vychází z př́edpokladu některých arménských politických komentátorů, že by v budoucnu mohlo dojít k rozpadu Turecké republiky. Důvodem 
rozpadu by podle nich měl být antagonismus mezi Kurdy a Turky, který údajně vzrůstá v souvislosti s kurdskou demografickou revolucí; počet dětí na jednu matku je totiž v kurdských rodinách dvakrát vyšší než v rodinách tureckých (Koc, Hancioglu, Cavlin 2008: 451). Kurdský nacionalismus a dokonce i separatismus podle těchto komentátorů navíc sílí v reakci na vznik „polonezávislého“ Kurdistánu na severu Iráku a také na rostoucí tlak EU na Ankaru, aby rozšírila kulturní a jazyková práva pro kurdskou menšinu. ${ }^{14}$

\section{Odmítání genocidy: turecký pohled}

Jak bylo zmíněno výše, aktuální diskuse o členství Turecka v EU způsobily, že uznání arménské genocidy se stalo důležitým tématem politického diskursu. Některé státy oficiálně uznaly arménské masakry jako genocidu, jiné s uznáním váhají, či jej dokonce odmítají. V každém př́padě však problém nevyřešené „osmanské minulosti“ související s osudy anatolských Arménů tvoři překážku na cestě Turecka do Unie. Označování zmiňovaných událostí za genocidu je tureckými soudy běžně hodnoceno jako „hanobení turecké národní identity“ podle známého 〔 301 odst. 1. zákona č. 5237 (trestního zákoníku). „Pachatel“ tak může být odsouzen na šest měsíců až tři roky.

Debata ohledně uznání genocidy se $\mathrm{v}$ tureckém prostředí zabývá především otázkou, lze-li zmíněné události vůbec klasifikovat jako genocidu. Důvodem $\mathrm{k}$ těmto pochybnostem je vedle námitek stran retroaktivity práva také nesouhlas s definicí genocidy, která je na tento prípad běžně aplikována. „Je otázkou, jestli turecká (sic!) vláda, at’ už slovem či činem, projevila záměr spáchat na arménském obyvatelstvu zvěrstva, která by dnes byla pokládána za genocidu“ (Yacoubian 2010: 58).

V Turecku se má za to, že samotný pojem „genocida“ byl poprvé použit až po událostech z roku 1915, a že jej tudíž coby právní termín nelze užívat retroaktivně. Tento argument se často opírá o stanovisko Mezinárodního centra pro tranziční spravedlnost, ${ }^{15}$ které tvrdí: „Mezinárodní právo obecně zakazuje retroaktivní užití smluv, pokud odlišný záměr nevyplývá ze smlouvy samotné, či není jinak opodstatněn. Úmluva o genocidě neobsahuje žádné ustanovení, které by umožňovalo její retroaktivní uplatnění“ (ICTJ 2002). ${ }^{16}$

Některé zdroje navíc dodávají, že v případě událostí z roku 1915 nelze prokázat, že bylo naplněno ustanovení Úmluvy o genocidě ohledně „úmyslu zničit“. Mümtaz Soysal, právník a bývalý politik, v této věci konstatoval, že: „[t]ato základní definice [úmysl zničit] pomáhá rozlišit mezi genocidou a jinými druhy zabití, které byly spáchány z jiných motivů, např. $\mathrm{v}$ důsledku válek, povstání apod. [...] je třeba objektivně studovat fakta, aby bylo prokázáno, zda takový záměr existoval, byt' jen implicitně. [...] Tato tragédie nemůže být nazývána genocidou, protože postrádá základní charakteristiku tohoto zločinu, a sice záměr vyhladit arménský národ jako takový. Je důsledkem válečné operace, o níž bylo rozhodnuto v atmosféře ozbrojeného konfliktu, v centru umírající říše sužované zmatkem a dezorganizací. Je zjevné, že přemístění arménského živlu mělo následky, které by na první pohled mohly naplňovat podmínky Úmluvy [o zabránění a trestání zločinu genocidia] z roku 194“8 (CSR 1998: 50). Soysal tedy tvrdí, že i když v důsledku přemístění došlo $\mathrm{k}$ úmrtím, stalo se tak kvưli nezodpovědnosti některých pověřených

\footnotetext{
${ }^{14}$ Blíže k této problematice viz Souleimanov (2006a).

15 Blíže ke konceptu tranziční spravedlnosti nap̌r. Oberphalzerová (2012).

16 Nutno ovšem dodat, že tato analýza hned v úvodu zřetelně tvrdí, že její závěry se týkají pouze užití slova „genocida“ v právním smyslu. Autoři prriznávají, že je možné tento termín užívat v akademických a publicistických textech i pro dobu před vznikem Úmluvy (ICTJ 2002).
} 
osmanských jednotek a kvưli extrémně tvrdým klimatickým podmínkám. Důvodem nebyl úmysl zničit arménskou populaci.

Současný tlak na Ankaru, aby uznala, že události z roku 1915 byly genocidou, je přijímán se značnou nevolí především $\mathrm{v}$ případě, kdy přichází z členských zemí EU. Je totiž vnímán jako další uměle vytvořená překážka, kterou nepřátelé Turecka vytvořili na jeho cestě k členství v Unii. Turecký historik Taner Akçam kriticky charakterizuje tuto mentalitu obklíčení přesvědčením, že „existují síly, které se nás ustavičně snaží rozprášit a zničit, a proti takovému nebezpečí je nezbytné stát bránit“ (Akçam 2004: 230). Tato mentalita, často označovaná jako „sèvreský syndrom“, se obecně vyznačuje představou, že „západní vlády se neustále pokouší rozložit území Turecka, podobně jako se o to neúspěšně snažily sèvreskou smlouvou“ (Hale 2000: 162). Někteří experti poznamenávají, že tato představa je integrální součástí turecké zahraniční politiky (Jung 2003).

Výše formulovaný názor může přispět $\mathrm{k}$ vysvětlení prudkosti turecké reakce na nedávný francouzský návrh zákona kriminalizujícího popírání genocidy Arménů. Např. turecký premiér Erdoğan prohlásil, že návrh je projevem ,[...] politiky založené na rasismu, diskriminaci a xenofobii. [...] Vyvolává znepokojení ohledně těchto otázek nejen ve Francii, ale v celé Evropě“ (Chrisafis, Hopkins 2011). V prohlášení vydaném po přijetí návrhu francouzským senátem Turecko prohlásilo, že je „odhodláno učinit všechny nutné kroky proti tomuto aktu nespravedlnosti, který ignoruje základní lidské hodnoty a veřejné svědomi““ (CNN 2012).

Otázka uznání genocidy Arménů $\mathrm{v}$ tureckém prostředí zesiluje polarizaci mezi „námi“ a „jimi“. Jak bylo zmíněno výše, byt' uznání genocidy není oficiální podmínkou vstupu do EU, některé členské státy tímto de facto podmínily svůj souhlas s príjetím Turecka. Ankara proto chápe celý problém jako odstrašující prostř̌edek, kterým chtějí některé země zabránit Turecku ve vstupu do EU. Kategorický nesouhlas s nedávným francouzským návrhem zákona spolu s neochotou Turecka uznat, že události z roku 1915 byly genocidou, tak vytváří napětí mezi státy uznávajícími arménskou genocidu, včetně některých členských zemí EU. To dále posiluje přesvědčení značné části turecké veřejnosti i elit, že problém uznání arménské genocidy byl některými státy instrumentalizován coby umělá překážka $\mathrm{v}$ př́stupovém procesu země do EU.

Ke způsobu, jakým turecká veřejnost vnímá masakry Arménů, k nimž došlo na počátku 20. století, navíc přispívá nedostatek informací, pramenící jednak z autocenzury a jednak ze všeobecné neochoty zabývat se věcmi, které nejsou oficiálně podporované (Maksudyan 2009). Tomuto informačnímu vakuu rovněž značně napomáhal fakt, že až do novely z roku 2008 bylo obhajování uznání deportací Arménů za genocidu trestné podle \301 (Algan 2008: 2238-2239). Vedle této donedávna platné právní překážky k rozvinutí otevřené debaty o tématu hraje značnou roli též oficiální pozice státu, kterou lze charakterizovat jako naprostou neochotu uznat arménskou genocidu. V nedávném prohlášení tureckého ministerstva zahraničí stálo: „Nadále budeme využívat své právo bránit se legitimními prostředky proti nepravdivým obviněním“ (The Telegraph 2012).

Důležitým faktorem přispívajícím $\mathrm{k}$ neochotě Turecka uznat arménskou genocidu je také postoj nejvyšších důstojníků turecké armády, kteří uvedená obvinění chápou jako nepř́stojnou urážku ozbrojených sil, tradičního strážce sekularismu v tureckém státě. V posledních letech země zažívá vzestup nacionalismu a odmítání „arménských lží, jak je genocida Arménů nazývána $\mathrm{v}$ pravicových vlasteneckých kruzích, se pozvolna stává součástí moderní turecké identity. Turecké ozbrojené síly byly výrazně oslabeny během vlády AKP, která podle některých zdrojů využívala vyšetřování kauzy Ergenekon (2007-2011) jako nástroj k oslabení opozice 
(Jenkins 2009: 10). V rámci vyšetřování bylo odsouzeno množství vědců, intelektuálů a vojenských důstojníků, kteři měli údajně být členy tajné sekularistické a nacionalistické organizace usilující o svržení vlády AKP. ${ }^{17}$ Zdá se tedy, že vedle oslabení armády dochází také k posilování pravicových nacionalistů, kteř́ jsou ostře proti uznání arménské genocidy.

Definitivní odmítnutí Unie udělit Turecku požadované členství by navíc v zemi mohlo být vnímáno jako selhání okcidentalizačního programu, který již ve dvacátých letech stanovil zakladatel republiky Mustafa Kemal Atatürk. Turecko se od té doby snaží integrovat do západního světa a v rámci tohoto úsilí podalo v roce 1987 přhlášku do EU (resp. ES). Nicméně status kandidátské země byl Turecku přiznán teprve v roce 1999 a př́stupové rozhovory byly zahájeny o šest let později. V dlouhodobé perspektivě by krach „evropského projektu“ mohl vést k narušení reputace kemalismu jako státní ideologie. Kemalismus přitom pokládá armádu za jednu z klíčových státních institucí, a už proto kemalistické elity, stejně jako armádní velení, nepokládají za žádoucí narušit pověst ozbrojených sil uznáním genocidy. Stoupence stávajícího uspořádání Turecké republiky tak ty členské země EU, které požadují uznání genocidy Arménů jako podmínku budoucího členství, staví před dilema, kdy zvolení libovolné z obou možností (uznat genocidu a vstoupit do EU, resp. neuznat genocidu a nevstoupit) naruší reputaci a legitimitu režimu. Dodejme, že $\mathrm{v}$ prŕpadě krize kemalismu lze $\mathrm{v}$ zemi očekávat posílení pravicových nacionalistů a islamistů, což se v omezené míře děje již nyní (lze říci, že současná vládní strana AKP ve své ideologii kombinuje umírněnější aspekty obou výše zmíněných ideologií, spolu s jistou měrou ekonomického liberalismu). ${ }^{18}$

Navíc je třeba dodat, že současná turecká vláda nepřišla s žádným oficiálním výkladem událostí z roku 1915, které jsou kvůli tlaku ze strany vlád a veřejností některých zemí EU dnes tolik diskutované. Obecně je v zemi rozšířen názor, že tyto události je tř̌eba vnímat jako pouhé deportace obyvatel arménské národnosti, kteří kolaborovali s Ruskem během jeho invaze do východní Anatolie. V turecké akademické literatuře se tak napr. cituje vyjádření zástupce Arménské revoluční federace z doby první světové války: „Arméni se bez sebemenšího zaváhání přidali na stranu Dohody; všechny své síly daly k dispozici Rusku, a nadto tvoří dobrovolnické oddíly“ (Uras 1976: 594). Spolupráce části arménské populace s ruskou armádou, tak, jak bylo formulováno ve výše uvedeném prohlášení, představuje klíčovou komponentu tureckého argumentu, že „opatření, podniknutá vůči východoanatolským Arménům, byla pouhým přemístěním do jiné části státu z bezpečnostních důvodů“ “. ${ }^{19}$

Podle oficiálního tureckého stanoviska byly tyto deportace výlučně vnitřní záležitostí Osmanské říše a jednalo se o nezbytné vojenské opatření. Turecká strana připouští, že během těchto opatření přišly o život desítky tisíc Arménů (dle některých oficiálních zdrojů až 300 tisíc). Nicméně kategoricky odmítá, že by tyto události měly být součástí širšího předem připraveného plánu na zničení celé národnostní menšiny (což je jedna z podmínek naplnění skutkové podstaty zločinu genocidia v právním smyslu). Dodávají, že během občanské války, hladomoru a epidemií v letech 1914-1918 přišly o život také stovky tisíc muslimů..$^{20} \mathrm{Na}$ podporu stanoviska, že osmanský stát neměl úmysl zmasakrovat arménskou populaci, se často cituje také dekret osmanské rady ministrů: „V době, kdy budou arménští obyvatelé výše zmíněných měst a vesnic,

\footnotetext{
17 Pro více informací o průběhu kauzy viz Balci (2010: 86-99).

${ }^{18}$ Více viz Souleimanov (2006b).

19 Srov. např. populární čtyřjazyčnou internetovou stránku Armenian Issue (2001a), jejíž vznik byl de facto iniciován tureckou vládou. Stránka obsahuje odkazy na množství dalších elektronických i tištěných zdrojů tvrdících, že ke genocidě nikdy nedošlo.

${ }^{20}$ Pro analýzu tureckého postoje k událostem viz Armenian Issue (2001b).
} 
kteři mají být přemístěni do nových míst pobytu, na cestě, musí jim být zajištěno pohodlí a jejich životy a majetky musí být chráněny“ (CSR 2007: 15-16).

Práce některých tureckých intelektuálů, zejména historiků žijících v západní Evropě, kteří mluví o potřebě formálně a legislativně uznat genocidu, je $\mathrm{v}$ současné době velmi důležitá $\mathrm{v}$ tureckém společenském diskurzu. Zmiňme alespoň několik prŕkladů, jako je Orhan Pamuk, Taner Akçam či Fikret Adanır. Orhan Pamuk, laureát Nobelovy ceny za literaturu (2006), byl v roce 2005 obviněn z vlastizrady skupinou právníků lobbujících za zájmy armády. Důvodem byla jeho vyjádření o arménské genocidě. Ač byl v první instanci shledán nevinným, v roce 2011 byl po zásahu Nejvyššího odvolacího soudu odsouzen k pokutě 6 tisíc tureckých lir (Kesler 2011).

Úsilí části turecké inteligence o formální uznání arménské genocidy je často zobrazováno jako nevlastenecké, zrádné, a neturecké. Uznání arménské genocidy je nadále společensky a politicky nepřijatelné, a navíc $\mathrm{v}$ opozici vůči postojům stále více podporovaných tureckých nacionalistů. Jak poznamenávají někteří členové turecké akademické obce, je pravděpodobné, že „čím více zahraničních parlamentů bude prohlašovat, že naši předkové spáchali zločiny proti lidskosti, tím méně je pravděpodobné, že někdo $\mathrm{v}$ Turecku bude ochoten vypořádat se $\mathrm{s}$ nejtěžšími momenty tureckých dějin“ (Clark 2007). Naopak, jiní turečtí akademici věří, že členství nebo perspektiva členství v Evropské unii snad umožní otevřenější diskusi o arménské tragédii a post-nacionalistických postojích vưči této kapitole v historii. Tomu do jisté míry odpovídá i vyjádření tureckého ministra pro evropské záležitosti Egemena Bağışe, který prohlásil, že každý národ má ve své historii nějaké temné momenty a že pokud by se „historicky a vědecky dokázalo“, že Osmanská říše skutečně spáchala na Arménech genocidu, Turecko by tento fakt prijialo a omluvilo se (Today's Zaman 2012)."

\section{Závěr}

Otázka uznání arménské genocidy je významnou součástí vnitropolitických diskursů jak v Turecku, tak v Arménii a má vliv na národní identity v obou zemích. V Turecku je uznání genocidy chápáno jako společensky a politicky nepřijatelné, zatímco u Arménů tato otázka působí jako sjednocující prvek jak $\mathrm{v}$ Arménské republice, tak $\mathrm{v}$ diaspoře. Povědomí o této tragédii arménského národa je nedílnou součástí současné arménské národní identity a přispívá k udržení vysokého stupně soudržnosti mezi Arménií a diasporou. Tato soudržnost je zásadní vzhledem k velkému počtu Arménů žijících v zahraničí a je jí dosaženo nejen díky zachování společného obrazu nepř́tele ( $v$ tomto smyslu Turecka), ale také prostřednictvím sdíleného pocitu př́slušnosti k „vlasti““ (Arménské republice, nebo podle některých k oblasti známé jako „Západní Arménie“). Kromě toho vidí někteří arménští politici a intelektuálové v uznání genocidy cestu $\mathrm{k}$ budoucímu dosažení finančního a územního odškodnění v podobě vrácení konfiskovaného majetku a možného znovupřipojení „Západní Arménie“ v návaznosti na jimi předpokládaný budoucí kolaps Turecka kvưli stupňujícímu se konfliktu mezi kurdskou a tureckou částí populace.

$\mathrm{V}$ Turecku je neochota oficiálně uznat arménskou genocidu často vnímána jako jeden $z$ důležitých faktorů přispívajících $\mathrm{k}$ faktu, že se zemi dosud nepodařilo vstoupit do EU. Rostoucí deziluze z kemalismu jako státotvorné doktríny a úpadek vlivu armády $\mathrm{v}$ turecké společnosti $\mathrm{v}$ důsledku rostoucího vlivu AKP posiluje pravicové nacionalisty a politické islamisty, kteří se proti uznání genocidy staví ještě vehementněji než stávající elity. Navíc události roku 1915 jsou tureckou veřejností vnímány jako pouhé přemístění arménského obyvatelstva z bezpečnostních důvodů, $\mathrm{k}$ nimž patřila především kolaborace Arménů s ruskými invazními silami. Nicméně současné Turecko je svědkem postupné změny percepce v prostředí intelektuálních elit, které 
př́ležitostně začínají obhajovat uznání genocidy, ale také spekulují o tom, zda by členství v EU či samotné úsilí o přistoupení nemohlo vést $\mathrm{k}$ otevřenější diskusi o událostech roku 1915 a snad i k př́padnému uznání arménské genocidy.

Mohlo by Turecko revidovat své oficiální stanovisko k problematice s ohledem na své úsilí o členství v EU, prípadně mohl by vstup do EU (a tlak ze strany členských států) vést v Turecku $\mathrm{k}$ otevřenější debatě o arménské tragédii? Odpověd’ závisí na pokroku Turecka směrem k přistoupení k EU. Současné napětí mezi Francií a Tureckem stran uznání arménské genocidy zřetelně ukazuje, že tato otázka v Turecku stále vyvolává značné kontroverze, přičemž současně představuje zásadní pojítko mezi Arménií a arménskou diasporou. $\mathrm{V}$ posledních letech $\mathrm{v}$ rámci širšího úsilí o sblížení vzniklo hnutí navrhující zapomenout na minulost a zaměřit se místo toho na budoucnost. Zapomnění na minulost a směřování kupředu je snad přijatelným řešením nejen pro zlepšení arménsko-tureckých vztahů, ale také na mezinárodní scéně, kde neochota Turecka uznat arménskou tragédii jako genocidu dlouhodobě destabilizuje vztahy mezi Tureckem a několika dalšími zeměmi včetně Francie a je ideologickou překážkou na cestě do EU. Uznání arménské genocidy je i nadále důležitým tématem vnitropolitického diskurzu obou zemí. Zatímco percepce událostí roku 1915 a otázka jejich (ne)uznání za genocidu je v Arménii i v Turecku formována především vnitřními konflikty a debatami obou societ, otázka formálního uznání genocidy ze strany třetích zemí je diskutované a politicky významné téma i na mezinárodní scéně.

\section{Literatura a prameny}

Açar, A. A. - Rüma, İ. (2007): External Pressure and Turkish Discourse on 'Recognition of the Armenian Genocide', Southeast European and Black Sea Studies, vol. 7, no. 3, s. 449-465. DOI: $10.1080 / 14683850701566419$

Ágoston, G. - Masters, B. (2009): Encyclopedia of Ottoman Empire, New York, Facts on File.

Akçam, T. (2004): From Empire to Republic: Turkish Nationalism and the Armenian Genocide, London, Zed Books.

Akçam, T. (2006): A Shameful Act. The Armenian Genocide and the Question of Turkish Responsibility, New York, Henry Holt and Company.

Algan, B. (2008): The Brand New Version of Article 301 of Turkish Penal Code and the Future of Freedom of Expression Cases in Turkey, German Law Journal, vol. 9, no. 12, s. 2237-2252.

Altinbaş, D. (2011): The "Armenian Question" in European Union Institutions, Review of Armenian Studies, no. 23, s. 147-232.

ANCA (2013): Genocide Rcognition, Washington, Armenian National Committee of America, on-line verze (http://www.anca.org/genocide/recognition.php), [cit. 07. 12. 2013].

ANI (2000): Sweden Parliament Report, Armenian National Institute, on-line verze (http://www.armenian-genocide.org/Affirmation.165/current_category.7/affirmation_detail.html), [cit. 3. 12. 2013].

Armenian Issue (2001a): What is genocide? Armenian Issue, allegations - facts, Ankara, Forsnet, on-line verze (http://www.ermenisorunu.gen.tr/english/intro/genocide.html), [cit. 3. 12. 2013].

Armenian Issue (2001b): Massacres of the Turks by Armenians. Armenian Issue, allegations - facts, Ankara, Forsnet, on-line verze (http://www.ermenisorunu.gen.tr/english/massacres/assesment.html), [cit. 3. 12. 2013].

Asbarez (2012): Aram I calls for return of stolen Armenian Churches, Asbarez, February 24, on-line verze, (http://asbarez.com/101190/aram-i-calls-for-return-of-stolen-armenian-churches/), [cit. 12. 08. 2012]. 
Avakian, A. V. (2010): A different future? Armenian identity through the prism of trauma, nationalism and gender, New Perspectives on Turkey, vol. 42, s. 203-214.

Bakalian, A. (1993): Armenian Americans: from being to feeling Armenian, London, Transaction Publishers.

Balci, A. (2010): A Trajectory of Competing Narratives: The Turkish Media Debate Ergenekon, Mediterranean Quarterly, vol. XXI, no. 1, s. 76-100. DOI: 10.1215/10474552-2009-035

Bartrop, P. R. (2001): The Holocaust, the Aborigines, and the bureaucracy of destruction: an Australian dimension of genocide, Journal of Genocide Research, vol. 3, no. 1, s. 75-87. DOI: 10.1080/14623520120037716

Baser, B. - Swain, A. (2009): Diaspora Design versus Homeland Realities: Case Study of Armenian Diaspora, Caucasian Review of International Affairs, vol. 3, no. 1, s. 45-62.

Bedrosyan, R. (2011): Special report: What is Turkey returning to Armenians?, The Armenian Weekly, August 31, on-line verze, (http://www.armenianweekly.com/2011/08/31/property-return/), [cit. 15. 02. 2012].

Beneš, V. (2008): Diskurzivní analýza, in: P. Drulák (ed.): Jak zkoumat politiku. Kvalitativní metodologie v politologii a mezinárodních vztazích, Praha, Portál.

Bilali, R. (2013): National Narrative and Social Psychological Influences in Turks' Denial of the Mass Killings of Armenians as Genocide, Journal of Social Issues, vol. 61, no. 1, s. 16-33.

Brave Heart, M. Y. H. - DeBruyn, L. M. (1998): The American Indian Holocaust: Healing Historical Unresolved Grief, American Indian and Alaska Native Mental Health Research, vol. 8, no. 2, s. 60 82. DOI: $10.5820 /$ aian.0802.1998.60

Bryce, V. - Toynbee, A. (1916): The Treatment of Armenians in the Ottoman Empire, 1915-1916. London, Sir Joseph Causton and Sons.

Bullough, O. (2010): Let Our Fame Be Great. Journeys Among the Defiant People of the Caucasus, Philadelphia, Basic Books.

Bürgin, A. (2010): Cosmopolitan Entrapment: The Failed Strategies to Reverse Turkey's EU Membership Eligibility, Perspectives: Central European Review of International Affairs, vol. 18, no. 2, s. 33-56.

Clark, B. (2007): Turkey's Armenia dilemma, BBC News, February 27, on-line verze (http://news.bbc.co.uk/2/hi/europe/6386625.stm), [cit. 19. 03. 2011].

CNN (2012): French Senate passes Armenian genocide bill, CNN, January 24, on-line verze (http://news.xinhuanet.com/english/world/2012-01/24/c_131375506.htm), [cit. 2012-03-18].

Cohen, R. (2008): Global Diasporas. An Introduction, Abingdon and New York, Routledge.

Cooper, B. - Akçam, T. (2005): Turks, Armenians, and the "G-Word", World Policy Journal, vol. 22, no. 3, s. 81-93.

CSR (1998): Armenian Claims and Historical Facts, Ankara, Center for Strategic Research.

CSR (2007): Armenian Genocide? Facts \& Figures, Ankara, Center for Strategic Research.

Dadrian, V. - Akçam, T. (2011): Judgment at Istanbul: The Armenian Genocide Trials, New York, Berghahn Books.

Dadrian, V. N. (1991): The Documentation of the World War I Armenian Massacres in the Proceedings of the Turkish Military Tribunal, International Journal of Middle East Studies, vol. 23, no. 4, s. 549576. DOI: $10.1017 /$ S0020743800023412

Dadrian, V. N. (1997): The Turkish Military Tribunal's Prosecution of the Authors of the Armenian Genocide: Four Major Court-Martial Series, Holocaust Genocide Studies, vol. 11, no. 1, s. 28-59. DOI: $10.1093 / \mathrm{hgs} / 11.1 .28$ 
Dadrian, V. N. (2004): The History of the Armenian Genocide: Ethnic Conflict from the Balkans to Anatolia to the Caucasus, Providence, Berghahn Books.

De Waal, T. (2012): Černá zahrada. Arménie a Ázerbájdžán v míru a za války, Praha, Academia.

Dixon, J. F. (2010): Defending the Nation? Maintaining Turkey's Narrative of the Armenian Genocide, South European Society and Politics, vol. 15, no. 3, s. 467-485. DOI: 10.1080/13608746.2010.513605

Dugan, L. et. al. (2008): Sudden desistance from terrorism: The Armenian Secret Army for the Liberation of Armenia and the Justice Commandos of the Armenian Genocide. Dynamics of Asymmetric Conflict, vol. 1, no. 3, s. 231-249.

EC (1993): European Council in Copenhagen, Conclusions of the Presidency DOC/93/3, on-line verze (http://europa.eu/rapid/press-release_DOC-93-3_en.htm?locale=en), [cit. 3. 12. 2013].

Edwards, D. - Potter, J. (2001): Discursive psychology, in: McHoul, A. - Rapley, M.: How to Analyse Talk in Institutional Settings, London and New York, Continuum.

EP (2006): Turkey's progress towards accession, European Parliament resolution 2006/2118(INI), on-line verze (http://www.europarl.europa.eu/sides/getDoc.do?pubRef=-//EP//NONSGML+TA+P6TA-2006-0381+0+DOC+PDF+V0//EN), [cit. 3. 12. 2013].

Foucault, M. (1994): Diskurz, autor, genealogie, Praha, Nakladatelství Svoboda.

Gregg, H. S. (2002): Divided They Conquer: The Success of Armenian Ethnic Lobbies in the United States. The Rosemarie Rogers Working Paper Series, Working paper \#13, Cambridge, MA, The Inter-University Committee on International Migration, on-line verze (http://web.mit.edu/cis/www/migration/pubs/rrwp/13_divided.pdf), [cit. 07. 12. 2013].

Gunter, M. M. - Rochtus, D. (2010): Special Report: The Turkish-Armenian Rapprochement, Middle East Critique, vol. 19, no. 2, s. 157-172. DOI: 10.1080/19436149.2010.484532

Gunter, M. M. (2011): Armenian History and the Question of Genocide, New York, Palgrave Macmillan.

Hakki, M. M. (2006): Turkey and the EU: Past Challenges and Important Issues Lying Ahead, Turkish Studies, vol. 7, no. 3, s. 451-471.

Hale, W. (2013): Turkish foreign policy since 1774, New York, Routledge.

Hovannisian, R. G. (2007): The Armenian Genocide: Cultural and Ethical Legacies, New Brunswick, Transaction Publishers.

Hülsse, R. (2006): Cool Turkey: Solving the Image Problem to Secure EU Membership, Mediterranean Politics, vol. 11, no. 3, s. 309-327. DOI: 10.1080/13629390600913908

Hyland, F. P. (1991): Armenian Terrorism, Boulder and Oxford, Westview Press.

Cheterian, V. (2010): Armenian genocide and Turkey: then and now, Open Democracy, April 24, on-line verze (http://www.opendemocracy.net/vicken-cheterian/armenian-genocide-and-turkey-then-andnow), [cit. 18. 9. 2012].

Chrisafis, A. - Hopkins, N. (2011): Turkey freezes all political relations with France over genocide row, Guardian, December 22, on-line verze (http://www.guardian.co.uk/world/2011/dec/22/turkeyfrance-freeze-relations-over-genocide), [cit. 18. 09. 2012].

ICG (2012): Armenia: An Opportunity for Statemanship, Europe Report No 217, Brussels, International Crisis Group, on-line verze (http://www.crisisgroup.org/ /media/Files/europe/caucasus/armenia/217-armenia-anopportunity-for-statesmanship.pdf), [cit. 07. 12. 2013].

ICTJ (2002): The applicability of the United Nations Convention on the Prevention and Punishment of the Crime of Genocide to events which occured during the early twentieth centrury, New York, 
International Center for Transitional Justice, on-line verze (http://ictj.org/sites/default/files/ICTJ-

Turkey-Armenian-Reconciliation-2002-English.pdf), [cit. 05. 08. 2011].

Jaimes, M. A. (ed.) (1992): The State of Native America. Genocide, Colonization and Resistance, New York, South End Press.

Jenkins, G. H. (2009): Between Fact And Fantasy: Turkey's Ergenekon Investigation, Silk Road Paper, Washington and Stockholm, Central Asia-Caucasus Institute \& Silk Road Studies Program, on-line verze (http://www.birolbasaran.com/ergenekon/Between_Fact_and_Fantasy-

Turkiyes_Ergenekon_investigation.pdf), [cit. 6.12.2013].

Jones, A. (2006): Genocide. A Comprehensive Introduction, London and New York, Routledge.

Jung, D. (2003): The Sevres Syndrome: Turkish foreign policy and its historical legacies, American Diplomacy, vol. VIII, no. 2, on line verze (http://www.unc.edu/depts/diplomat/archives_roll/2003_07-09/jung_sevres/jung_sevres.html), [cit. 12. 08. 2012].

Kelly, M. J. (2008): Genocide - The Power of a Label, Case Western Reserve Journal of International Law, vol. 40, no. 1-2, 147-162.

Kérvorkian, R. (2011): The Armenian Genocide: A Complete History, New York, I. B. Tauris.Kiernan, B. (2007): Blood and Soil. A World History of Genocide and Extermination from Sparta to Darfur, New Haven, Yale University Press.

Kesler, M. (2011): Nobel laureate Orhan Pamuk gets fined, Hürriet Daily News, March 27, on-line verze (http:/ / www.hurriyetdailynews.com/default.aspx?pageid=438\&n=orhan-pamuk-will-paycompensation-for-his-words-court-decided-2011-03-27), [cit. 05. 12. 2013].

Koc, I. - Hancioglu, A. - Cavlin, A. (2008): Demographic Differentials and Demographic Integration of Turkish and Kurdish Populations in Turkey, Population Research and Policy Review, vol. 27, no. 4, s. 447-457.

Košt’álová, P. (2011): Arménské kroniky od jezera Van: 16.-18. století, Červený Kostelec, Pavel Mervart. Kuper, L. (1981): Genocide: Its Political Use in the Twentieth Century, Harmondsworth, Penguin Books. Kurtiş, T. - Adams, G. - Yellow Bird, M. (2009): Generosity or genocide? Identity implications of silence in American Thanksgiving commemorations, Memory, vol. 18, no. 2, 208-224.

Lepsius, J. (1919): Deutschland und Armenien 1914-1918. Sammlung diplomatischer Aktenstücke, Potsdam, Tempelverlag.

Lomsadze, G. (2011): Georgia Recognizes Circassian Genocide, Eurasianet, May 20, on-line verze (http://www.eurasianet.org/node/63530), [cit. 07. 12. 2013].

Lowell, L. B. - Gerova, S. G. (2004): Diasporas and Economic Development. State of Knowledge. Prepared for World Bank, Washington, Institute for the Study of International Migration, on-line verze (http://siteresources.worldbank.org/INTPROSPECTS/Resources/3349341322593305595/8287139-1327608098427/LowellDiaspora.pdf), [cit. 07. 12. 2013].

Maksudyan, N. (2009): Walls of Silence: Translating the Armenian Genocide into Turkish and SelfCensorship, Critique: Journal of Socialist Theory, vol. 37, no. 4, s. 635-649.

Mammadov, G. (2011): Nagorno-Karabakh Conflict: Armenia's Victory or Nightmare?, Foreign Policy Journal, October 13, on-line verze, (http://www.foreignpolicyjournal.com/2011/10/13/nagornokarabakh-conflict-armenias-victory-or-nightmare-2/), [cit. 18. 9. 2012].

Manaseryan, T. (2004): Diaspora. The Comparative Advantage for Armenia, Working Paper No. 04/14, Washington: Armenian International Policy Research Group, on-line verze (http://aiprg.net/UserFiles/File/wp/jan2004/14.pdf), [cit. 07. 12. 2013]. 
Martin, J. J. (1981): Raphael Lemkin and the invention of 'genocide', The Journal of Historical Review, vol. II, no. 1, s. 19-34.

MFA (2011a): Nagorno-Karabakh issue, Ministry of Foreign Affairs of the Republic of Armenia, on-line verze, (http://www.mfa.am/en/artsakh/), [cit. 18. 9. 2012].

MFA (2011b) Bilateral relations - Turkey, Ministry of Foreign Affairs of the Republic of Armenia, on-line verze, (http://www.mfa.am/en/country-by-country/tr/), [cit. 18. 9. 2012].

Morgenthau, H. (1918): Ambassador Morgenthau's story, New York, Doubleday.

Moses, D. A. (2004): Genocide and Settler Society. Frontier Violence and Stolen Indigenous Children in Australian History, New York and Oxford, Berghahn Books.

Moshman, D. (2001): Conceptual constraints on thinking about genocide, Journal of Genocide Research, vol. 3, no. 3, s. 431-450. DOI: 10.1080/14623520120097224

Mustafayeva, A. - Garayev, R. (2013): Legal Aspects of Reparation for Damage Caused to Azerbaijan as a Result of Armenian Aggression, IRS Heritage, vol. 14, s. 50-61.

Mutafyan, L. (2011): Preservation of Armenian Identity is Encouraged, Hayern Aysor, October 13, on-line

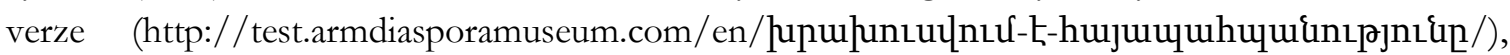
[cit. 20. 09. 2012].

Nekvapil, J. (2006): Úvodem k monotematickému číslu „Analýza promluv a textů, analýza diskurzu“, Sociologický časopis, roč. 42, č. 2, s. 263-268.

Oberpfalzerová, H. (2012): Tranziční spravedlnost a proces národního usmírení v Bosně a Hercegovině, Mezinárodní vztahy, roč. 47, č. 3, s. 5-28.

Oğuzlu, H. T. (2012): Turkey and the European Union: Europeanization Without Membership, Turkish Studies, vol. 13, no. 2, s. 229-243. DOI: 10.1080/14683849.2012.685256

Papazian, D. R. (1995): The Struggle for Personal and Collective Identity: The Ukrainian and Armenian Experience in America, Journal of American Ethnic History, vol. 14, no. 3, s. 52-56.

Parliament (2006): Assyrian and Armenian Genocide in 1915, Early Day Motion 1454, on-line verze (http://www.parliament.uk/edm/2005-06/1454), [cit. 3. 12. 2013].

Paul, R. A. (2000): Grassroots mobilization and Diaspora politics: Armenian interest groups and the role of collective memory, Nationalism and Ethnic Politics, vol. 6, no. 1, s. 24-47. DOI: 10.1080/13537110008428586

Peterson, S. (2010): Turkey cancels summit with Sweden over Armenian genocide resolution, The Christian Science Monitor, March 12, on-line verze (http://www.csmonitor.com/World/GlobalNews/2010/0312/Turkey-cancels-summit-with-Sweden-over-Armenian-genocide-resolution), [cit. 07. 12. 2013].

Petrosjan, J. V. (2011): Genocid armjan: voprosy vozmeščenija matěrialnogo uščerba (reparacii i kompensacii), Jereven, Sankt-Petěrburskij institut vněšněekonomičeskich svjazej, ekonomiki i prava, filial v g. Jerevaně, on-line verze, (http://www.spbivesep.am/genocid/elena.pdf), [cit. 02. 05. 2012].

Phillips, D. L. (2012): Diplomatic History: The Turkey-Armenia Protocols, New York, Institute for the Study of Human Rights.

Poulton, H. (2000): The Muslim Experience in the Balkan States, 1919-1991, Nationalities Papers, vol. XXVIII, no. 1, s. 45-66. DOI: 10.1080/00905990050002452

Richmond, W. (2013): The Circassian Genocide, New Brunswick, Rutgers University Press.

Shain, Y. (1994): Ethnic Diasporas and U.S. Foreign Policy, Political Science Quarterly, vol. 109, no. 5, s. 811-841. DOI: $10.2307 / 2152533$

Siroky, D. S. - Dzutsev, V. (2012): Rational or reckless? Georgia's zugzwang in the Caucasus, Nationalities Papers, vol. 40, no. 3, s. 303-314. DOI: 10.1080/00905992.2012.685063 
Souleimanov, E. (2006a): The Politics of France's Genocide Denial, Central Asia - Caucasus Analyst, vol. VIII, no. 20, s. 6-8.

Souleimanov, E. (2006b): Bezpečnostní aspekty př́padného členství Turecka v Evropské unii. Středoevropské politické studie, roč. VIII, č. 2-3, s. 298-313.

Suleymanov, E. (ed.) (2006): Khojaly Genocide (in documents, facts and foreign press), Baku İnkişafina Yardım Assosiasiyası.

Suny, R. G. - Göçek, F. M. - Naimark, N. N. (2011): A Question of Genocide : Armenians and Turks at the End of the Ottoman Empire, Oxford, Oxford University Press.

Suny, R. G. (1993): Looking toward Ararat. Armenia in Modern History, Bloomington and Indianapolis, Indiana University Press.

Tait, R. - MacAskill, E. (2010): Turkey threatens "serious consequences" after US vote on Armenian genocide, The Guardian, March 5, on-line verze (http://www.theguardian.com/world/2010/mar/05/turkey-us-vote-armenian-genocide), [cit. 07. 12. 2013].

Tatz, C. (2001): Confronting Australian genocide, Aboriginal History, vol. 25, no. 1, s. 16-38.

The Telegraph (2012): Turkey attacks France over Armenian 'genocide' bill, The Telegraph, January 24, on-line verze (http://www.telegraph.co.uk/news/worldnews/europe/france/9034755/Turkeyattacks-France-over-Armenian-genocide-bill.html), [cit. 18. 03. 2012].

Today's Zaman (2012): If Armenian 'genocide' proven, Turkey will apologize, says Bağış, Today's Zaman, February 5, on-line verze (http://www.todayszaman.com/news-270579-if-armenian-genocideproven-turkey-will-apologize-says-bagis.html), [cit. 3. 12. 2013].

Tölölyan, K. (1992): Terrorism in modern Armenian political culture. Terrorism and Political Violence, vol. 4, no. 2, s. 8-22. DOI: 10.1080/09546559208427146

Tölölyan, K. (2000): Elites and Institutions in the Armenian Transnation, Diaspora: A Journal of Transnational Studies, vol. 9, no. 1, s. 107-136. DOI: 10.1353/dsp.2000.0004

UN (1948): Convention on the Prevention and Punishment of the Crime of Genocide, Adopted by Resolution 260 (III) A of the United Nations General Assembly, New York.

Uras, E. (1976): Tarihte Ermeniler ve Ermeni Meselesi, Istanbul, Belge Yayınlar1.

Valigholizadeh, A. - Zaki, Y. - Barani, K. Z. (2013): An analytical study of geopolitical consequences of normalization of Turkish-Armenian relations, Journal of Eurasian Studies, vol. 4, no. 2, s. 197-206. DOI: $10.1016 /$ j.euras.2013.03.009

Vidlickova, A. (2012): Turkish-Armenian Relations and the Issue of the Recognition of the claims of the Armenian genocide, Alternatives: Turkish Journal of International Relations, vol. 11, no. 1, s. 1-16.

Wald, P. M. (2007): Genocide and Crimes Against Humanity, Washington University Global Studies Law Review, vol. 6, no. 3, 621-633.

Walker, C. J. (1997): World War I and the Armenian Genocide, in: R. G. Hovannisian (ed.): The Armenian People from Ancient to Modern Times, volume II, New York, St. Martin's Press.

Yacoubian, G. S. (2010): Financial, Territorial, and Moral Reparations for the 1915 Armenian Massacres, War Crimes, Genocide \& Crimes against Humanity, vol. 4, s. 59-98.

Zekian, B. L. (2010): Armenian-Turkish Relations in the Framework of Turkish and Armenian Scholarships, Iran and the Caucasus, vol. 14, no. 2, s. 367-385.

\section{Recognition of the Armenian Genocide as an Issue in Political Discourse in Armenia, Turkey and selected EU Countries}




\section{SUMMARY}

The dilemma underlying Armenian genocide recognition has long surpassed its purely moral and historical context, becoming a highly politicized and up-to-date issue with significant ramifications in the field of international politics. This question is not purely limited to current relations between Armenia and Turkey, but has also entered the European sphere through the Armenian and Turkish diasporas and through the question of Turkish accession to the EU. Although the issue of the Armenian genocide has been researched quite extensively from a historical perspective, producing often controversial results, the political implications of the recognition or non-recognition of genocide have scarcely been addressed. The purpose of this article is to fill this gap through the exploration of the political implications of the recognition or denial of the Armenian genocide. This objective is accomplished through a focus on the perceptions of Armenia, Turkey, and other nations (especially within the EU) of the 1915 events and a focus on the rationale of these nations on whether or not these events should be classified as genocide. An overview of the 1915 events will be provided, followed by an assessment of EU standpoints on whether or not these events should be recognized as genocide. These standpoints will be assessed primarily in the context of Turkey's efforts to become an EU member. The article then focuses on the internal discourses among Armenians and Turks on this matter, and the motive behind Armenia's calls for other nations to recognize the Armenian genocide and Turkey's unwillingness to do so. The method used in this article involves analyzing various Turkish, Armenian, and European positions presented in academic and media sources in order to capture the differing perspectives on this issue in both the international and local arenas.

The events that took place in Armenia between 1915 and 1916 are considered by some to be the 20th century's very first genocide. Historically, massacres of Armenians were initiated when Armenian Christians sought the protection of the Ottoman Empire from attacks by Kurdish tribes. In response, fearing European intervention on behalf of Christians, the Ottoman military, together with semi-military Kurdish units, seemingly carried out these initial massacres between 1894-1896. These units were subject to minimal supervision by the central power of the Ottoman government. Subsequently, in WWI, antagonism between Armenians and Muslims reached an all time high when the governing Turkish party ordered the deportation and (according to some sources) massacres of the Armenian population. These actions led to the displacement and death of between 800,000 and 1.5 million Armenians.

Today, Armenians in the diaspora, with lobbies and a significant political role in the international scene, have often called on Turkey to recognize the genocide and on international governments to pressure Turkey to do so. Official statements by a number of EU member states and by the European Parliament suggest that Turkey's recognition of the genocide would be deemed highly favorable with respect to its case for accession to the EU. Accordingly, Armenia's interest in Turkish recognition of the genocide lies beyond transparent ethical and moral reasoning; Armenia's advocacy for Turkey's recognition of the genocide and the branding of Turkey as the "enemy", especially following Turkey's involvement in the Nagorno-Karabakh conflict in favor of Azerbaijan, serves to maintain social cohesion within Armenia and among the Armenian diaspora and, thereby, may slow the assimilation process of the Armenian diaspora. In more practical terms, recognition of the genocide is advocated by Armenia with a view to receiving financial reparations from Turkey regarding confiscated Armenian property as well as making a possible future territorial claim with respect to Western Armenia.

However, recognition of the Armenian genocide is a delicate subject in Turkey, wherein public reference to the Armenian genocide is considered an attempt to disparage the Turkish national identity 
and is punishable by imprisonment. One of the major arguments used against recognition is derived from the lack of any legal definition of genocide until more than 30 years after the 1915 events. Another popular argument is that an 'intent to destroy', as stipulated in the legal definition of genocide, cannot be proven in regard to the 1915 events. Turkish officials point to documents of the time ordering 'deportation' as evidence that no deliberate massacre plans were ordered. In addition, many in Turkey feel that EU pressure to recognize the genocide is yet another tool of obstruction to its accession to the EU. This perception of anti-Turkish sentiment is known as Sevres Syndrome and, according to some scholars, plays a crucial role in Turkish foreign policy, as may be demonstrated by French-Turkish tensions over a recent French bill recognizing the genocide. The Turkish public, in turn, may be influenced by censorship or the reluctance to acknowledge events which are not officially supported. With the growth of Turkish nationalism, recognition of the Armenian genocide would present a slap in the face to the Turkish army and to increasingly powerful right-wing forces. Indeed, in light of the growth of such right-wing forces, the rejection of Turkish accession may likely be interpreted not as the failure of Turkey to recognize the genocide but, rather, as the failure of Turkey's pro-Western legacy, and even lead to radicalization. Furthermore, there is no unified official standpoint on the Armenian issue, although there is a popular viewpoint that the massacres should be perceived as unfortunate and unplanned repercussions of the deportation of the Armenian population, which had collaborated with the Russians in the invasion of Anatolian territory.

This article concludes that the issue of the recognition or denial of the Armenian genocide is a political stumbling block toward normalized relations between Armenia and Turkey and toward Turkey's accession to the EU. This subject consumes internal and political discourses within Armenia and within Turkey. For Armenia, the subject serves as a rallying point against Turkey and a consequent unifying factor for the Armenian population. Yet, with the decline of Kemalism, and the growing influence of the AKP, Turkey is presently highly unlikely to recognize the 1915 events as genocide. The question of whether or not these events will be considered genocide in the future, particularly by Turkey, will depend on internal developments within the country, EU pressure, and the status of Armenian-Turkish relations. Thus, although societal perceptions of the issue of acknowledging the Armenian genocide are largely shaped by internal tensions and debates in Armenia and Turkey, this highly contested issue holds political significance also in the international arena. 